\title{
TAFSIR AYAT-AYAT KASIH SAYANG DALAM MASYARAKAT PLURAL
}

\author{
Bambang Irawan \\ IAIN Sumatera Utara \\ bambangirawan@yahoo.com
}

\begin{abstract}
Islam sangat menghargai harkat kemanusiaan universal, menganjurkan hidup dengan damai dan saling menyayangi. Melakukan kekerasan dan pembunuhan terhadap seorang manusia tanpa ada alasan yang benar, sama halnya dengan telah membunuh manusia sejagat. Namun, di tengah riuhnya tuntutan tersebut, muncul paradoks: yaitu intensitas ritual keagamaan menjadi sangat romantik dan marak, namun dalam kehidupan sehari-hari belum mampu melahirkan kesalehan diri, apalagi kesalehan sosial. Kehidupan beragama tampak meriah dalam rutinitasnya, namun tanpa disertai dengan keprihatinan dan tanggung jawab sosial. Tulisan berikut adalah upaya sederhana menggali dan menafsirkan ayat-ayat al-qur'an yang terkait dengan cara hidup yang damai dan kasih sayang dalam masyarakat yang plural.
\end{abstract}

Kata Kunci: solidaritas sosial, inklusif, ekslusif, plural.

\section{PENDAHULUAN}

Secara normatif, tidak ada satupun agama yang membenarkan atau menganjurkan pemeluknya untuk melakukan tindak kekerasan (violence). Akan tetapi, secara faktual, tidak jarang dijumpai tindak kekerasan yang dilakukan masyarakat agamis. Bahkan, ada kecenderungan bahwa kekerasan ini justru dilakukan oleh mereka yang mempunyai basic agama yang kuat dan melakukannya dengan atas nama agama. Apa yang terjadi di Sulawesi Tengah, Maluku, dan Aceh, ${ }^{1}$ juga di Afganistan, Pakistan, India, Palestina dan Irlandia adalah bukti-bukti yang menyatakan hal itu.

Di dalam problem sosial sejatinya seseorang justru akan menemukan basis ketakwaannya dalam bentuk praksis solidaritas sosial kemanusiaan. ${ }^{2}$ Inilah makna juga yang dimunculkan oleh Ali Asghar Engineer dalam rumusan teologi pembebasannya. ${ }^{3}$

Paling tidak ada tiga tipe sikap yang ditunjukkan umat: ekskusif, 
inklusif, dan pluralis. ${ }^{4}$ Sikap eksklusif adalah pandangan yang menolak adanya kerja sama antar umat beragama, karena masing-masing mengklaim dirinya sebagai yang paling benar. ${ }^{5}$ Sikap inklusif adalah pandangan yang sudah mampu dan mau melakukan hubungan dan kerja sama dengan pihak lain, tetapi hanya pada dan atas dasar kepentingan social, karena apa yang benar hanya pada dirinya sendiri. Sikap pluralis adalah paradigma pemikiran yang berpendapat bahwa setiap agama mempunyai kebenaran dan jalan keselamatan sendiri-sendiri sehingga tidak ada alasan untuk menolak kerja sama di antara mereka. Bukan sekedar alasan sosiologis melainkan teologis. ${ }^{6}$

Tidak dapat dipungkiri misi suci yang dibawa Nabi Muhammad saw ke dunia ini adalah adalah menciptakan harmoni, ketentraman, kedamaian, dan kebahagiaan dalam kehidupan manusia. Inilah yang menjadi kondisi cita ideal yang dikehendaki oleh setiap anak manusia. Menjadi rahmat bagi seluruh alam berarti Islam anti kekacauan, anti kekerasan dan anti penderitaan. Salah satu makna rahmat itu adalah kebaikan atau kedamaian. Artinya kehadiran Islam di muka bumi ini untuk kebaikan dan kedamaian alam ini. Jadi Islam sangat menyayangi alam sekitarnya. Jangankan kepada manusia, kepada binatang pun Islam mengajarkan tidak memperlakukannya secara kasar. Jika ingin menyembelih hewan, maka sembelihlah dengan pisau yang tajam; jika ingin memeliharanya, maka peliharalah dengan memenuhi hak-haknya; jika ingin mengendarainya, maka tunggangilah dengan cara yang baik, begitu seterusnya.

\section{ISLAM AGAMA RAHMAT DAN KASIH SAYANG}

Menjadi rahmat bagi seluruh alam juga berarti menjunjung tinggi harkat seluruh makhluk. Pengrusakan terhadap alam dan tindak kekerasan terhadap manusia adalah paradoks dengan cita-cita dan misi Islam. Jika pengrusakan dan tindak kekerasan itu dilakukan oleh seseorang yang memiliki ketaatan simbolik-formalistik yang tinggi sekalipun,ak berkontribusi pada kemaslahatan yang lebih luas keimanan orang tersebut dapat dikatakan palsu. Secara spesifik Allah Swt. berfirman (QS. al$\mathrm{Ma}>$ 'u $>$ n/107: 1-7): "tahukah kamu (orang) yang mendustakan agama? Itulah mereka orang suka menghardik anak yatim, dan tidak menganjurkan memberi makan kepada orang miskin, maka kecelakaan akan menimpa orang-orang yang shalat, yaitu orang-orang yang lalai dari shalatnya, orangorang yang berbuat dengan pamrih dan enggan menolong dengan barang yang fungsional".

Dalam perspektif ini dapat dikatakan bahwa seseorang yang 
mengklaim dirinya sebagai Muslim berarti secara sadar pula ia akan menciptakan kedamaian dalam seluruh aspek kehidupannya. Sebab Islam ditinjau dari akar katanya berarti "damai" berasal dari kata salam. Sehingga seluruh aspek ibadah ritual dalam Islam sebenarnya memiliki pesan damai, bahkan pesan-pesan damai itu didemonstrasikan secara simbolik dan harus dipenuhi sebagai bagian dari pelaksanaan ibadah (rukun atau syarat syah ibadah). Kesalehan formalitas dan kesalahan sosial harus diimplementasikan secara integral-konperhensif. Ketiadaan salah satu dari dua aspek ini akan mengakibatkan yang lainnya palsu. Tetapi suatu hal yang pasti bahwa iman yang meniscayakan kita tunduk patuh dan pasrah kepada aturan Tuhan, sesungguhnya adalah untuk manusia juga. Sehingga iman yang tidak bisa membedayakan dan memberi rasa damai berarti iman seperti itu palsu.

Secara sosiologis Allah Swt. menciptakan manusia yang berbeda satu dengan yang lainnya dalam multi-etnik dan multi religius, pada sebagai suatu kesimbangan dan untuk saling melengkapi. Kemudian saling menyapa, saling berkompetisi dalam kebajikan untuk kemakmuran hidup. Bukan untuk saling berbantah-bantahan yang mengakibatkan kekerasan dan pembunuhan antara sesama manusia (QS. al-H $\{$ ujura $>\mathrm{t} / 49$ : 13). Larangan saling membunuh karena semua manusia pada dasarnya adalah umat yang satu yang diciptakan oleh Allah Swt. Diciptakan berbeda merupakan kehendak Ilahi bukan kehendak kita manusia. Maka jangan memperselisihkan perbedaan, apatah lagi merusak perbedaan itu karena perbedaan (multi-etnik dan multi religius) sosial-kemasyarakatan, sesungguhnya menjadi tatanan kesempurnaan sistem kemanusiaan universal (QS. al-Baqarah/2: 213). Sebab manusia merupakan bagian dari eksistensi alam, olehn karena itu membunuh manusia berarti telah merusak tatanan eksistensi kosmis yang telah diciptakan Allah Swt. Firman Allah Swt. (QS. Yu>nus/10: 86). "Dan janganlah kalian membuat kerusakan di muka bumi setelah Allah memperbaikinya ...".

Al-Quran secara tegas menyebutkan jalan hidup damai yang mesti ditempuh oleh manusia agar terhindari dari kekacauan dan kekerasan, di antaranya penyebutan salah satu nama Allah as-Sala $>m$, yang Maha Damai (QS. al-H \{aysr/59: 23); barang siapa yang ingin memperoleh keridhaan Allah swt, harus ditempuh melalui subulus salam (jalan-jalan damai) (QS. al-Ma 'idah/5: 16). Surga sebagai tempat kembali orang-orang yang beriman dan beramal shaleh, dalam Al-Qur'an disebut dengan Daar asSalam, (rumah yang damai), (QS. al-An'a $>\mathrm{m} / 6:$ 127) dan (QS. Yu>nus/10: 25).

Berdasarkan uraian di atas, jelas bahwa anti kekerasan dan cinta kedamaian adalah bagian dari ajaran agama, sekaligus merupakan cita ideal 
kemanusiaan universal. Namun demikian dalam kehidupan berkelompok apatahlagi dalam masyarakat yang plural, konflik yang dapat mengarah kepada kekerasan merupakan keniscayaan.

Dengan demikian untuk membangun kehidupan yang anti kekerasan dan cinta damai, memerlukan transformasi pemahaman agama, dari pemahaman yang terlalu individualistik-ritualistik dan terlalu elitis- eskatologis kepada pemahaman integratif dan konprehensif, yaitu aspek kesadaran eksistensi yang Ilahi (periketuhanan), akan memberi kesadaran perikemanusiaan.

Ayat-ayat di atas menunjukan Islam sangat anti kekerasan. Allah swt tidak menyukai orang melakukan tindak kekerasan yang merusak (QS. alBaqarah/2: 205). Karena aktivitas fasad (merusak) akan menghancurkan kedamaian dan kebahagiaan manusia. Tindak kekerasan akan selalu menimbulkan rasa kebencianm, sedangkan anti kekerasan akan melahirkan rasa cinta. Kekerasan merupakan akar dari kehancuran, sementara anti kekerasan jalan menunju islah (rekonsiliasi) dan perdamaian.

Al-Qur'an mempersiapkan segala apa saja yang dibutuhkan umat manusia khususnya kebutuhan spiritual. Ayat-ayat soal perdamaian dapat dengan mudah kita temukan dalam al-Qur'an. Begitu pula ayat-ayat yang sepintas mengajarkan tindakan kekerasan terhadap pihak lain. Ayat tentang toleransi dan pengakuan keberadaan agama dan keyakinan yang berbeda juga mudah kita temukan begitu pula sebaliknya. Misalnya ayat-ayat berikut ini:

Banyak sekali ayat yang memerintahkan kita untuk senantiasa menebarkan kebaikan, tidak memaksakan yang lain, kasih sayang, pengasih, pemaaf, pemurah, dan mencintai untuk mencapai kebenaran sejati, misalnya QS. al-Baqarah/2: 256]; QS. al-H \{ujura $>$ t/49: 13; QS. Ali-'Imra $>$ n/3: 103; dan QS. al-Baqarah/2: 263. Sejak awal Nabi Muhammad saw telah mengajarkan kita untuk saling toleransi yang luhur seperti QS. al-Baqarah/2: 272, tidak boleh saling mencaci seperti dalam QS. al-An'a $>\mathrm{m} / 6$ : 108, keadilan, kebersamaan dan persaudaraan seperti QS. al-Ma''idah/5: 8, perdamaian dalam segala hal, pemurah dan pecinta, kebaikan dan kesadaran, kesopanan dan rasa hormat kepada siapa pun seperti QS. alAnbiya>/21: 107; dan QS. al-Mumtah\}anah/60: 8.

Untuk mencapai tujuan-tujuan itu al-Quran mengajarkan kasih sayang sebagai visi universal ajaran Islam. Firman Allah swt: "Dan tidaklah kami mengutus engkau selain untuk membawa 'rahmat' bagi semesta alam". (QS. al-Anbiya>/21: 107)

Kata 'rahmat' atau kasih sayang yang menjadi prinsip ajaran 
kemanusian dalam ayat tersebut jelas bertolak belakang dengan gagasan kekerasan. Untuk mempertegas gagasan ini Al-Qur'an bahkan menyebut kata 'rahmat' sebanyak 114 kali. Itu berarti penyebutan kata ini sama banyaknya dengan jumlah surat dalam Al-Qur'an. Hal itu juga menunjukkan kitab suci ini menjadikan kasih sayang sebagai prioritas ajaran. Terkait dengan itu Rasulullah bersabda: "Muslim ialah seorang yang memberikan keamanan pada orang lain dari keburukan lisan dan tangannya" (HR. Bukhari dan Muslim)

Hadis ini menunjukkan Rasulullah saw. mengajarkan agar setiap orang menjaga keselamatan orang lain dengan tidak membiarkan dirinya terlibat menyakiti orang lain, baik dengan ucapan maupun tindakan. Prinsip dalam hadis ini menjadi dasar menegasikan kekerasasan dalam Islam.

\section{DAKWAH DENGAN DAMAI TANPA KEKERASAN}

Dakwah, pada hakikatnya, adalah upaya menyeru kepada manusia untuk memenuhi dan melaksanakan panggilan agama Allah. Dakwah ini menempati posisi penting dalam agama Islam. Islam sangat peduli pada keselamatan manusia dari kesesatan dan pengingkaran pada Allah. Karena itu, Islam berupaya menyelamatkan sebanyak-banyaknya umat manusia di dunia. Sesungguhnya, bukan hanya manusia yang hendak diselamatkan Islam, tetapi seluruh dunia (alam semesta). Manusia melalui ajaran agamanya, diserukan untuk senantiasa berbuat kebajikan baik kepada Tuhan, sesamanya maupun lingkungannya.

Menurut Fazlur Rahman, tujuan utama al-Quran adalah menegakkan sebuah tata masyarakat yang adil, berdasarkan etika, dan dapat bertahan di muka bumi. Maksudnya adalah seruan dakwah pada hakikatnya untuk mendorong manusia berbuat kebajikan seperti yang diwajibkan Allah yang semuanya itu bermanfaat bagi kebahagiaan manusia sendiri.

Nabi Muhammad saw. telah mencontohkan bagaimana berdakwah yang elegan dan santun. Keteladan moral, sikap, perilaku, pikiran maupun ucapannya menjadi senjata ampuh dalam menghimpun umat secara lebih cepat. Bangsa Arab dan daerah sekitarnya telah mengalami banyak perubahan oleh dakwah Nabi Muhammad baik dari sisi keagamaan, kemasyarakatan, politik, maupun moralitas. Bangsa Arab telah dibuat berdaya dan bergerak cepat dapat capaian-capaian peradaban sesudah wafatnya. Para khalifah penggantinya dengan semangat yang setia pada ajaran dakwah nabi Muhammad saw telah berhasil memekarkan ekspansi Islam ke seluruh dunia dari Maroko hingga ke Merauke. Kecermelangan ini, 
sungguh, merupakan catatan sejarah yang tak mungkin diraih tanpa keunggulan-keunggulan. Dakwah Nabi Muhammad saw dilakukan dengan prinsip-prinsip yang dipenuhi kelembutan, egalitarianisme, kemanusiaan, dan penuh keadilan. Dasar-dasar inilah yang nampaknya menjadi kekuatan dahsyat melampaui kekuatan senjata dan pasukan.

Al-Quran telah berpesan kepada umat Islam untuk melakukan dakwah dengan damai dan tanpa kekerasan. Allah berfirman: "Serulah (manusia) ke jalan Tuhanmu dengan hikmah dan pelajaran yang baik dan berargumentasilah dengan mereka dengan yang baik (pula). Sesungguhnya Tuhanmu, Dialah yang paling mengetahui siapa yang tersesat dari jalanNya, dan Dialah yang lebih mengetahui orang-orang yang mendapat petunjuk'. (QS. an-Nah\}1/16: 125)

Dakwah haruslah bersifat persuasif dan tidak memaksakan kehendak. Sebab tindakan memaksa bukan saja tidak diperkenankan, lebih jauh justru akan membuat orang yang didakwahi atau diajak kepada Islam akan semakin menjauh.

"Tidak ada paksaan dalam memeluk agama (Islam). Sesungguhnya telah jelas (perbedaan) antara yang benar dan yang sesat". (QS. Ali Imran/3: 256)

Dalam berdakwah ini seorang muslim tidaklah boleh menjelekkan agama lain. Hal tersebut selain tidak etis juga akan melahirkan konflik antar umat beragama dan aksi balasan yang serupa. Sementara visi yang diinginkan Allah adalah kedamaian antar umat beragama. Islam tidak mentolelir segala aksi yang menimbulkan konflik antar manusia. Sebaliknya, Islam mengajarkan umatnya bersikap santun dan toleran terhadap perbedaan. Islam menganggap aksi kekerasan dalam menyampaikan gagasan justru akan membuat orang lain lari dari ajaran Islam. Karenanya, Al-Qur'an memuji sikap Nabi yang lemah lembut. Sebab seandainya Nabi memaksakan kehendak dan melakukan kekerasan maka orang yang mendengarnya akan lari tunggang-langgang.

Al-Qur'an juga tidak membenarkan berkata-kata kasar dalam berdakwah, akan tetapi berkatalah dengan lemah lembut, termasuk dalam mengajak orang untuk melakukan kebaikan. Perhatikanlah firman Allah: "Maka disebabkan rahmat dari Allah-lah kamu berlaku lemah lembut terhadap mereka. Sekiranya kamu bersikap keras lagi berhati kasar, tentulah mereka menjauhkan diri dari sekelilingmu. Karena itu ma'afkanlah mereka, mohonkanlah ampun bagi mereka." (Qs. Ali Imran/3: 159). 


\section{PENGAKUAN TERHADAP AGAMA LAIN}

Menurut Tuhan, manusia adalah umat yang satu (Q.S. al-Baqarah/2: 213), tetapi perbedaan pendapat muncul merajalela karena keras kepala, egosentrisme, dan membesar-besarkan perbedaan. Tetapi, perbedaan itu dipandang sebagai cara Tuhan untuk menguji manusia. Al-Qur'an menyatakan bersedia mengubah perpecahan menjadi kebahagiaan dengan memberikan tantangan: "Maka berloma-lombalah dalam kebajikan..." (QS. al-Ma>'idah/5: 48; al-Baqarag/2:148; dan al-Mu'minu>n/23: 16).

Pluralitas (kemajemukan, keragaman) merupakan ketetapan sekaligus pembe-rian Tuhan yang paling unik kepada manusia. Jika keunikan Tuhan terletak pada "Keesaan, Kemahasempurnaan dan Kemahamutlakan"-Nya, keunikan manusia justeru terlihat pada kemajemukan, ketidaksempurnaan dan keterbatasannya. Dalam kemajemukan, manusia belajar hidup bersama. Karena ketidaksempurnaannya, manusia belajar mencari makna kebenaran, kebaikan dan keindahan. Dan, karena keterbatasannya, manusia belajar untuk tahu diri dan menyadari eksistensinya sebagai bagian dari realitas hidupnya yang terikat dengan ruang dan waktu.

Dengan Keesaan-Nya, Tuhan menjadi Sumber, Asal dan Muara segala kebe-naran, kesempurnaan, kebaikan, keindahan, dan keserbamutlakan. Kemahamutlakan-Nya menjadikan-Nya tidak terikat dengan ruang dan waktu. Dia hadir, melampaui batas-batas ruang, waktu dan segala yang ada di luar diri-Nya. Karena itu, wajar Dia menjadi poros, muara dan tujuan manusia dalam beribadah, berdo'a dan mengadukan segala urusan dalam hidupnya.

Harus diakui, bahwa agama-agama, disamping memiliki klaim absolutisme, juga memiliki klaim inklusivisme. Dalam konteks ini ada kasus menarik yang pernah dialami oleh Nabi Muhammad, yaitu ketika kaum musyrik bersikeras menolak ajaran Islam, maka demi kemaslahatan bersama Tuhan memerintahkan kepada Nabi untuk berkata kepada mereka: “...Tuhan kelak akan menghimpun kita semua, kemudian Dia memberi keputusan diantara kita dengan benar. Sesungguhnya Dia Maha Pemberi Keputusan lagi Maha Mengetahui".

Menurut penafsiran Quraish Shihab ketika absolutisitas diantar ke luar (ke dunia nyata), Nabi tidak diperintahkan untuk menyatakan apa yang ada di dalam (keyakinan tentang absolutisitas agama tersebut), tetapi justru sebaliknya. Itulah sebabnya menurut Quraish Shihab, bahwa salah satu kelemahan manusia adalah semangatnya yang menggebu-gebu, sehingga ada di antara mereka yang bersikap melebihi Tuhan, misalnya meng- 
inginkan agar seluruh manusia satu pendapat, menjadi satu aliran dan satu agama. Semangat yang menggebu-gebu ini pulalah yang mengantarkan mereka memaksakan pandangan absolutnya untuk dianut orang lain.

Jika agama memang menyumbang perdamaian, maka penganut agama harus belajar meninggalkan absolutisme dan menerima pluralisme, demikian ungkap Nurcholish Madjid. Kita boleh memandang agama sebagai absolut, namun yang harus diingat bahwa pemahaman kita --baik pribadi maupun kelompok-- menyimpan kualitas kemanusiaan yang relatif. Petunjuk konkret untuk memupuk persaudaraan menurut Nurcholish adalah, supaya suatu kelompok dari kalangan orang-orang beriman tidak memandang rendah atau meremehkan orang dan agama lain.

Huston Smith, dalam memberikan komentar karya Schuon mengenai hubungan antar agama-agama, mengatakan bahwa segala sesuatu memiliki persamaan dan sekaligus perbedaan, demikian juga dengan agama. Agamaagama yang hidup di dunia ini disebut "agama" karena masing-masing memiliki persamaan. Persamaan atau titik temu antara agama-agama tersebut berada pada level esoterisme, sedangkan pada level eksoterieme, agama-agama tampak berbeda. ${ }^{9}$

Menurut Raimundo Panikkar ${ }^{10}$, untuk memahami agama-agama orang lain secara komprehensif, kita harus memahami agamanya melalui bahasa aslinya. Kita tidak bisa mengabaikan perbedaan-perbedaan yang ada dalam masing-masing agama untuk menarik kesimpulan bahwa "semua harus menjadi satu". Menurutnya, ada tiga macam sikap keagamaan manusia: eksklusif, inklusif dan paralel/ plural. Sikap ekslusif artinya, seseorang menganggap bahwa hanya agamanya saja yang benar, sementara yang lain salah; sikap inklusif artinya seseorang beranggapan, bahwa agamanya yang paling benar, tetapi agama lain juga mengandung kebenaran; sikap plural artinya, seseorang menganggap bahwa semua agama sama dan mengandung kebenaran masing-masing.

Terkait dengan hal ini Armahedi Azhar mengatakan bahwa terdapat lima penyakit yang menghinggapi para aktivis gerakan keagamaan, yaitu: absolutisme, ekslusivisme, fanatisme, ekstremisme dan agresivisme. Absolutisme adalah kesombongan intelektual, ekslusivisme adalah kesombongan sosial, fanatisme adalah kesombongan emosional, ekstremisme adalah sikap yang berlebihan dan agresivisme adalah tindakan fisik yang berlebihan.

Dialog antar umat beragama yang benar dapat menimbulkan pemahaman dan pencerahan kepada umat dalam wadah kerukunan hidup antarumat beragama. ${ }^{12}$ Dalam dialog ini diperlukan sikap saling terbuka antarpemeluk agama yang berdialog. Sebenarnya menganggap bahwa 
agama yang dipeluk itu adalah agama yang paling benar bukanlah anggapan yang salah, bahkan yakin bahwa agama yang ia peluk adalah agama yang paling benar, dan orang lainpun dipersilahkan untuk meyakini bahwa agama yang ia peluk adalah agama yang paling benar. Malapetaka akan timbul apabila orang yang yakin bahwa agama yang ia peluk adalah agama yang paling benar, lalu beranggapan bahwa karena itu orang lain harus ikut ia untuk memeluk agama yang ia peluk. ${ }^{13}$

Dengan tegas dikatakan oleh Mudji Sutrisno, bahwa tidak cukup membangun dialog antaragama hanya dengan dialog-dialog logika rasional, namun perlu pula logika psikis. Maka ikhtiar dialog teologi kerukunan juga harus dibarengi dengan pencairan-pencairan psikologis, seperti rasa saling curiga yang selama ini selalu muncul. Memang, seperti juga yang diungkap oleh Kautsar Azhari, bahwa kendala dialog antar umat beragama adalah persoalan eksklusivisme. Seorang eksklusivis akan terus berusaha agar orang lain mengikuti agamanya dengan menganggap agama orang lain keliru dan tidak selamat (truth claim).

Tentu saja dengan masih adanya konflik antar umat pada beberapa tahun terakhir ini tidak bisa dikembalikan begitu saja kesalahannya pada pendekatan dialog secara an sich sebab disamping ada faktor-faktor lain yang ikut ambil bagian di dalamnya seperti ekonomi, hukum, politik dan seterusnya. Sudah saatnya kini para pemuka agama mulai mengedepankan misi agama yang terkait dengan masalah spiritualitas dan persoalan kemanusiaan (kasih sayang, keadilan, kejujuran, dan keramahan). Oleh sebab itu, salah satu hal yang perlu diperhatikan dalam rangka menciptakan kerukunan umat beragama di tengah pluralitas ini adalah dengan memahami ajaran agama masing-masing secara utuh.

Ketegangan agama yang terjadi selama ini adalah karena pelaku dakwah (da'i, pastur, missionaris) adalah orang-orang yang cinta pada agamanya, tetapi tidak memiliki pengetahuan agama secara mendalam. Akibatnya dakwahnya lebih cenderung propagandis dan provokatif. Salah satu metode mengurangi terjadinya konflik antar-agama di Tanah Air kita yang notabene pluralistik ini adalah dengan melepaskan klaim-klaim kebenaran (truth claim) dan doktrin penyelamatan yang berlebihan, berani mengoreksi diri atas keberagamaan kita. Pandangan keagamaan yang semacam ini akan membawa kita pada cara beragama yang, inklusif, dan pluralis, sehingga kita pun optimistis atas masa depan agama yang lebih baik. Dengan demikian, simbol dalam agama-agama tidak menjadikan seseorang merasa takut bertegur sapa, berdialog, dan bekerja sama untuk merespons masalah-masalah sosial kemanusiaan yang menghadang di 
depan agama-agama.

\section{PERANG SEBAGAI PILIHAN TERAKHIR}

Islam sangat menghormati fitrah manusia saat terjadinya peperangan dengan melakukan pembatasan-pembatasan secara ketat demi penghormatan terhadap hak asasi manusia tersebut. Dalam peperangan, agar tetap di Jalan Allah dan tidak melebihi batas atau membabi buta, Islam melarang umatnya untuk; membunuh orang yang tidak terlibat langsung dengan peperangan seperti membunuh perempuan dan anak-anak, atau membunuh yang sedang beribadah. Islam juga melarang merusak pepohonan, tempat-tempat ibadah, fasilitas umum dan mencincang mayat. Islam juga mengharuskan sebelum terjadi peperangan terlebih dahulu ditawarkan kepada pihak musuh 3 hal; masuk Islam, membayar jizyah (pajak) atau berperang. Dan Islam sangat menekankan untuk lebih berharap perdamaian daripada terjadinya peperangan saat tiga tawaran itu diajukan. Itulah yang dimaksud bahwa Allah tidak menyukai hal-hal yang berlebihan sekalipun dalam situasi peperangan.

Sejarah dunia mencatat, Rasulullah menegur sahabatnya yang membunuh musuh saat mengucapkan syahadat. Jenderal besar Khalid bin Walid membiarkan kemahnya tidak dibongkar saat peperangan karena diatasnya ada burung yang sedang bersarang dan penunggang kuda ulung sahabat Rasulullah bernama Abu Qatadah memberikan air wudhunya ketika seekor kucing menghampiri berharap minum.

"Dan perangilah di jalan Allah orang-orang yang memerangi kamu, tetapi jangan melampaui batas. Sungguh, Allah tidak menyukai orangorang yang melampaui batas." (QS. al-Baqarah/2: 190)

Dalam ayat tersebut Allah memerintahkan berperang namun dengan syarat harus tetap di jalan Allah yang diterjemahkan dalam bentuk perang yang tidak melebihi batas. Perang yang tetap menghormati hak-hak kemanusiaan. Perang yang tidak seperti perang bar-barnya kaum selain Islam. Perang yang memang menjadi salah satu Sunnatullah yang harus dijalani saat keadaan mengharuskan demikian. Dalam kondisi tertentu umat Islam memang harus berperang, sebagaimana yang telah terjadi pada masa Nabi Muhammad SAW. Tetapi peperangan itu bukan memaksa orang untuk masuk Islam, juga tidak memaksa orang mengikuti kebenaran yang kita yakini. Perang yang beradab dengan pemenuhan terhadap syarat dan rukunnya. Inilah perang dalam Islam.

Jihad dalam bentuk peperangan dapat dilakukan karena dua hal: pertama 
mempertahankan diri (self defense) jika diserang oleh umat lain. Hal ini dapat dilihat dalam surat at-Taubah ayat 13: Mengapakah kamu tidak memerangi orang-orang yang merusak sumpah (janjinya), padahal mereka telah keras kemauannya untuk mengusir Rasul dan merekalah yang pertama mulai memerangi kamu? Mengapakah kamu takut kepada mereka padahal Allah-lah yang berhak untuk kamu takuti, jika kamu benar-benar orang yang beriman. Kedua, melawan terhadap tekanan (protection from oppression) yang dilakukan umat lain. Hal ini juga dilakukan sebagai upaya untuk melindungi diri dari kejahatan-kejahatan pihak lain yang telah sengaja memusuhi dan menyerang umat Islam (baca: QS. al-Baqarah/2: 190-195).

Dengan demikian, kekerasan dalam bentuk perang bukan dimulai oleh umat Islam sendiri. Begitu pula dalam sejarah perjungan nabi Muhammad SAW, perang badar, uhud, dan lainnya bukanlah umat Islam yang mengundang kaum kafir, akan tetapi sebaliknya. Umat Islam justru diperintahkan untuk tetap berbuat baik kepada siapa pun, termasuk kepada non-muslim yang dapat hidup rukun. Mengenai hal ini, Allah juga berfirman dalam surah Al Mumtahanah ayat 8 dan 9 "Allah tidak melarang kamu berbuat baik dan adil terhadap orang-orang yang tidak memerangi kamu dalam agama dan tidak mengusir kamu dari kampung-kampungmu sebab Allah senang kepada orang-orang yang adil. Allah hanya melarang kamu bersahabat dengan orang-orang yang memerangi kamu dalam agama dan mengusir kamu dari kampung-kampungmu dan saling bantu-membantu untuk mengusir kamu ,barangsiapa bersahabat dengan mereka maka mereka itu adalah orang-orang yang zalim".

Hukum Islam mengakui dan menjamin hak-hak asasi manusia, bukan hanya kaum Muslim tetapi juga penganut agama lain yang disebut ahli kitab. Kalaupun terjadi pelanggaran dalam masyarakat Islam, itu bukan disebabkan oleh ajaran Islam tetapi karena ketidaksempurnaan manusia yang menerima Pesan Ilahi. Manusia memiliki kekurangan dan tidak ada satupun agama yang dapat menghilangkan kekurangan ini sepenuhnya.

\section{PENUTUP}

Jika kita baca ayat demi ayat dalam al-Qur'an sebagaimana yang dipaparkan, maka sangat jelas bahwa yang ditampilkan al-Qur'an adalah kepedulian terhadap hubungan kemanusiaan yang harmonis dan saling menyayangi. Karena itu ironis jika masih ada pemeluk agama yang mensikapi perbedaan dan kemajemukan sebagai ancaman (bukan rahmat). Ini menunjukkan cara berpikir dan proses pemahaman yang sempit. Jika demikian, 
pendidikan memiliki peran strategis untuk mengembalikan cara berpikir dan sikap peserta didik ke dalam tataran yang mengerti (dan memahami) pluralitas bermasyarakat. Pendidikan yang diselenggarakan haruslah pendidikan yang paham betul terhadap problem akut kemanusiaan seperti penindasan, kemiskinan, pembantaian dan sebagainya. Pendidikan yang dilaksanakan bukan merupakan penanaman wacana dalam fungsi organisatorisnya yang lebih mengedepankan terma perebutan wilayah dan pengikut. Karena pendidikan seperti ini hanya akan menampakkan ekspresi kecurigaan terus menerus dalam prosesnya dan antar sivitas pendidikan. Pendidikan seperti ini juga merupakan upaya pendangkalan wacana keagamaan.

Dalam masyarakat yang relatif majemuk seperti di Indonesia pendidikan agama harus memberikan gambaran dan idealitas moral agamanya secara kontekstual. Di sini dipersyaratkan peninjauan ulang atas doktrin-doktrin agama yang kaku. Seperti halnya jihad bukan dipahami sebagai persetujuan Islam untuk menggunakan kekerasan dalam menyebarkan agama. Melainkan, berarti mengubah sistem yang didasarkan pada istikbar (keangkuhan kekuasaan dan eksploitasi) dan istidh'af (penekanan dan penindasan) serta penolakan terhadap yang munkar (ketidakadilan).

Adalah tugas para tokoh agama untuk mengeluarkan Islam dari wajah seram, keras, kaku dan anti dialog. Dan menyadarkan umat bahwa Islam bukanlah sekedar kumpulan khabar tentang amal ritual yang jika dilaksanakan akan mendapat imbalan surga, tetapi lebih dari itu umat harus mampu membawa Islam sebagai agama yang memiliki kekuatan potensial yang mampu menumbuhkan rasa kasih sayang dan tanggung jawab dalam diri manusia, menggelorakan dinamika semangat berkorban dan berjuang sehingga agama benar-benar mampu menjadi rahmat bagi seluruh alam. Hal ini tidak mungkin dicapai kecuali dengan merekonstruksi doktrin-Islam dan memfungsikan agama sebagai sumber, wadah, ekspresi, seta manifestasi pencarian makna hidup manusia melalui aktualisasi kemanusiaan.

Kerancuan yang mewabah di kalangan umat Islam dewasa ini adalah penyamarataan antara agama yang sakral dengan pemikiran keagamaan yang profan, yang merupakan hasil usaha memahami teks-teks agama. Sehingga, setiap usaha untuk membenahi atau mengganti kekurangan metodologi pemikiran sebagai pusaka turun-temurun, divonis telah merubah agama, syari'ah, bahkan dikafirkan. Tradisi, menyalahkan dengan berlebihan dan kafir-mengkafirkan, merupakan cerminan umat yang berpikiran sempit. Ini merupakan penyakit kronis yang sukar disembuhkan. Dengan demikian penafsiran-penafsiran ayat-ayat terdahulu tentang perang yang berpotensi menimbulkan potensi konflik, diskriminatif dan 
menyimpang dari nilai-nilai dan prinsip-prinsip Islam yang damai, berkeadilan, demokratis dan berspektif kesetaraan manusia dihadapan Allah, harus segera dikonstruk ulang untuk menampilkan wajah Islam yang benar-benar pantas'menjadi rahmat bagi seluruh alam.[]

\section{Catatan Akhir:} 198.

${ }^{1}$ Muslim Abdurrahman, Islam Transformatif (Jakarta: Pustaka Firdaus, 1995), h.

${ }^{2}$ Dalam teologi pembebasan lebih menekankan pada praksis daripada teoritisasi metafisis yang mencakup hal-hal yang abstrak dan konsep-konsep yang ambigu. Praksis yang dimaksud adalah sifat liberatif dan menyangkut interaksi dialektis antara "apa yang ada" dan "apa yang seharusnya". Menafsirkan tauhid bukan hanya sebagai keesaan Tuhan, namun juga sebagai kesatuan manusia yang tidak akan benar-benar terwujud tanpa terciptanya masyarakat yang adil. Selengkapnya, lihat Asghar Ali Engineer, Islam dan Teologi Pembebasan, terj. Agung Prihantoro (Yogyakarta: Pustaka Pelajar, 1999).

${ }^{3}$ Alwi Shihab, Islam Inklusif, (Bandung, Mizan, ), h. 84-45, Budhy Munawar Rahman, Islam Pluralis, (Jakarta, Paramadina, 2000), h. $44-49$

${ }^{4}$ John Lyden (ed), Enduring Issues In Religion, (San Diego: Greenhaven Press Inc, 1995), h. 63 .

${ }^{6}$ Budhy Munawar-Rachman, Islam Pluralis, h. 46

${ }^{7}$ Fazlur Rahman, Tema Pokok al-Qur'an, terjemah Anas Mahyudin (Bandung: Penerbit Pustaka, 1983), h. 54.

${ }^{8}$ Perhatikan QS. Saba/34: 24-26.

${ }^{9} \mathrm{~F}$. Schuon, The transcendent Unity of Religions. Wheston (Illinois: The Theosophical Publishing House, 1984), h. xii.

${ }^{10}$ Ramundo Pannikar, Dialog Intra Religius (Yogyakarta: Kanisius, 1994), h. 17

${ }^{11}$ Ibid., h. 18.

${ }^{12}$ Mathews, World Religion (Canada: International Thompson Publishing, 1999), h. $432-433$.

${ }^{13}$ Mukti Ali, Ilmu Perbandingan Agama (Bandung: Mizan, 1998), h. 67-68. 


\section{DAFTAR PUSTAKA}

Abdurrahman, Muslim, Islam Transformatif (Jakarta: Pustaka Firdaus, 1995).

Ali, Mukti, Ilmu Perbandingan Agama (Bandung: Mizan, 1998).

Engineer, Asghar Ali, Islam dan Teologi Pembebasan, terj. Agung Prihantoro (Yogyakarta: Pustaka Pelajar, 1999).

Lyden, John, (ed), Enduring Issues In Religion, (San Diego: Greenhaven Press Inc, 1995)

Mathews, World Religion (Canada: International Thompson Publishing, 1999).

Munawar-Rahman, Budhy, Islam Pluralis, (Jakarta, Paramadina, 2000).

Pannikar, Ramundo, Dialog Intra Religius (Yogyakarta: Kanisius, 1994).

Rahman, Fazlur, Tema Pokok al-Qur'an, terjemah Anas Mahyudin (Bandung: Penerbit Pustaka, 1983).

Schuon, F., The transcendent Unity of Religions. Wheston (Illinois: The Theosophical Publishing House, 1984).

Shihab, Alwi, Islam Inklusif, (Bandung: Mizan, 1999). 